Yurii Orlov suffers two trials

"Dissidence is an occupational hazard of the scientist!" This was the message delivered last autumn to the Venice Biennale on cultural dissent by Valentin Turchin, a cyberneticist, foundermember of the (illicit) Moscow group of Amnesty International and currently a political expellee.

The same theme was re-iterated yet again this week by the 'Orlov Hearing' at the Institute of Physics in London. This was a mock-trial in which John Macdonald, Q.C. presented the case for the defence simultaneously with the official trial in Moscow of Yurii Orlov, formally on a charge of slandering the Soviet state, de facto for his membership of the Helsinki monitoring group.

The case of Orlov-a corresponding member of the Academy of Sciences of the Armenian SSR-has attracted considerable attention throughout the world, not least because he is the highest-ranking Soviet scientist to be brought to trial on a political charge since the death of Stalin.

According to $\mathrm{Mr}$ Macdonald, a sufficient defence in Soviet law would be constituted by a proof that the data circulated in the information bulletins

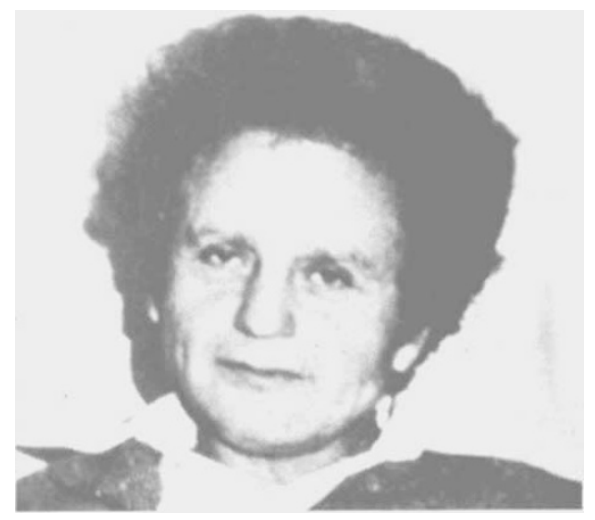

of Orlov's 'Helsinki group' was true. Hence much of the evidence dealt with such abstruse points as the rights of the Crimean Tartars to return to their historic homeland, the rights of poor Ukrainian workers to emigrate to Canada, and the rights of a Baptist or Pentecostal to educate his children in his own faith-all of which are technically guaranteed either by the Soviet consitution, or by the various international human rights conventions to which the Soviet Union is a signatory.

However, as Turchin pointed out in Venice, it is standard scientific practice to apply the criteria of truth and consistency to all that one observes. It is not surprising, therefore that Orlov and his associates in Moscow (who included dissident Anatolii Shcharanskii, himself now awaiting trial, and Madame Elena Bonner, the wife of Academician
Andrei Sakharov) were concerned not with this or that particular abuse, but the whole concept of human rights.

The particular abuses reported at the hearing are, alas, now commonplace; political dissenters in psychiatric hospitals tied to their beds and denied the "privilege" of using the W.C., subjected to "reforming" doses of psychotropic drugs, or, as in the recent case of Nikolaev, refused a visit from next of kin due to foreign protests.

"Orlov's most characteristic trait," said Andrei Amalrik, co-founder of the Helsinki Monitoring Group, "is that he is not an emotional person. Before he makes a judgment, he verifies the facts thoroughly."

According to reliable reports, Orlov, while in pre-trial custody, has completed two scientific papers, one on symbolic logic, and one on elementary particle physics.

\section{Vera Rich}

- Message from Dr Robert Kates, Chairman of the Human Rights Committee of the US National Academy of Science :

'Many scientists around the world will be watching carefully the outcome of the trial commencing today for signs that the Soviet legal process is responsive to its own constitutional guarantees of freedom of thought and opinion. Yurii Orlov is a distinguished Soviet scientist who has contributed significantly to his country's inesrimable progress in science. One only hopes that he will be dealt with fairly and justly in the proceedings taking place today. We will be watching . .."

\title{
Re-usable satellite the future for UK space research?
}

IF Britain's space science lobby has its way, some of Britain's space-borne experiments in the $1980 \mathrm{~s}$ will be carried by an American re-usable satellite. The satellite, the 'multimission modular space craft (MMS)', is now under development at the Goddard Space Center in the US.

The space shuttle will spawn MMS satellites, leaving them aloft when the shuttle returns to Earth. Its attractions to Britain's space scientists are that it is cheap, re-usable, and powerful. It can be bought in kit form for $\$ 9 \mathrm{~m}$ and assembled at home; and the three large modules of the MMS-providing power, attitude control, and data handling-can cope with $3,000 \mathrm{~kg}$ of astronomical instrumentation.

According to Professor Ken Pounds, X-ray astronomer of Leicester University, the MMS should have arcsec pointing accuracy and could serve Britain for some 15 or 20 years. In that time, three or four experiments could be launched around the same MMS package. The first experiment, including the whole MMS and instrument costs might amount to $£ 10 \mathrm{~m}$. Discounting over five years - the time the experiment might last-the costs amount to $£ 2 \mathrm{~m}$ a year. This is "no more than the old Skylab programme" said Pounds, and considerably less than the present British spending in ESA, the European Space Agency.

The cost of Britain's participation in ESA amounts to an $£ 8 \mathrm{~m}$ subscription, paid through the Science Research Council, and a current $£ 5$ to $£ 6 \mathrm{~m}$ spent on research projects. In addition another $130 \mathrm{~m}$ is paid by the Department of Industry which contributes to ESA applications, and to work on Spacelab, communications, the MAROTS satellite, Ariane launch technology, and the Uhuru launch base.

A number of European space scientists are becoming dissatisfied with ESA. And in the UK, where space science budgets are steadily shrinking against a fixed ESA subscription, the dissatisfaction is growing. Next year's UK6 will be the last British research satellite. "If in two or three years we had only $£ 4 \mathrm{~m}$ to spend on research projects, you would get a $100 \%$ UK vote to come out of ESA", Pounds said last week.
"ESA runs perhaps one mission for us every two years. There are five scientific fidisciplines and that leaves each one with a flight every 10 years. That's not value for money". Taking small amounts of space on US satellites helps out, says Pounds, but competition is intense and there is a natural bias towards US experiments. The MMS is the only way that Britain can keep up with world space science in the 1980s, thinks Pounds. "Otherwise we will be left with the fag ends of other people's missions."

- The Appleton Laboratory at Slough, which manages Britain's satellites (including UK5 at present and UK6 to follow), is to be moved to the Rutherford Laboratory some 40 miles away, if the recommendations of a Science Research Council rationalisation committee are accepted. Appleton has done little satellite engineering; and the Rutherford needs to find work for its accelerator engineers when Nimrod closes on 6 June. The result may be a team "which can get us more of the ESA action" said Professor Pounds last week.

Robert Walgate 